https://ejournal.iai-tribakti.ac.id/index.php/perbankan

\title{
Kompleksitas Pembiayaan Ijarah Multijasa Dalam Fatwa Dewan Syari'ah Nasional Nomor 44 Tahun 2004 Perspektif fiqh muamalah maliyyah
}

\section{The Complexity of Multiservice Ijarah Financing in the Fatwa of the National Syari'ah Council Number 44 of 2004 Muamalah maliyyah fiqh perspective}

\author{
Jamaluddin ${ }^{1}$ A. Hasyim Nawawie ${ }^{2}$ \\ ${ }^{1}$ Institut Agama Islam Tribakti Kediri, ${ }^{2}$ Institut Agama Islam Negeri Tulungagung \\ ${ }^{1}$ jamaluddin.bukhori02@gmail.com, ${ }^{2}$ nawawie_hasyim@yahoo.com
}

\begin{abstract}
The Islamic economic system (Islamic finance) grows and develops in various countries, both in areas where the majority of the population is Muslim and Muslim minorities. The Islamic economic system (Islamic finance) is not only considered part of the teachings of Islam, but a view and attitude of life that is lawful (prohibited transactions), in the framework of forming the welfare of the people. The public's perception of sharia economics (Islamic finance) actually consists of 3 (three) variables, namely 1) the perception of multi-service contracts related to bank profit sharing, 2) muamalah maliyyah fiqh system related to bank profit sharing, 3) Islamic bank products 'ah itself. This research is quantitative in nature with a positivistic paradigm design. In this paper it is done using reference study techniques. For this reason, the researchers took references as many as 20 (twenty) books (books) that have a correlation with this paper. The findings of this paper indicate that first, the perception of using Islamic banking products (multujasa ijrah contract). Second, the system uses Islamic banking products. Third, Islamic bank products do not affect the public's interest in using Islamic banking products, the multujasa ijarah contract with the perspective of fiqh muamalah maliyyah.
\end{abstract}

Keywords: Multiservice Ijrahah, DSN-MUI Fiqh Muamalah Maliyyah.

\begin{abstract}
Abstrak
Sistem ekonomi syariah (keuangan syariah) tumbuh dan berkembang di berbagai negara, baik di kawasan negara yang mayoritas penduduknya muslim maupun muslimnya minoritas. Sistem ekonomi syariah (keuangan syariah) tidak hanya dianggap sebagai
\end{abstract}


bagian dari ajaran islam, tetapi pandangan dan sikap hidup yang halal (transaksi yang dilarang), dalam rangka terbentuknya kesejahteraan umat. Persepsi masyarakat tentang ekonomi syariah (keuangan syariah) sesungguhnya terdiri dari 3 (tiga) variabel, yaitu 1) persepsi tentang akad multijasa yang berkaitan dengan bagi hasil bank, 2) sistem fiqh muamalah maliyyah yang berkaitan dengan bagi hasil bank, 3) produk bank syari'ah itu sendiri. Penelitian ini bersifat kuantitatif dengan desain paradigma positivistik. Dalam tulisan ini dilakukan dengan menggunakan teknik studi referensi. Untuk itu peneliti mengambil referensi sebanyak kurang lebih 20 (dua puluh) buku (kitab) yang ada korelasinya dengan tulisan ini. Temuan tulisan ini menunjukkan bahwa pertama, persepsi tentang menggunakan produk bank syariah (akad ijrah multujasa), Kedua, sistem menggunakan produk perbankan syariah. Ketiga, produk bank syariah tidak berpengaruh terhadap minat masyarakat yang menggunakan produk perbankan syariah, akad ijarah multujasa perspektif fiqh muamalah maliyyah.

Kata Kunci: Ijrahah Multijasa, DSN-MUI, Fiqh Muamalah Maliyyah.

\section{A. Pendahuluan}

Perkembangan ekonomi Islam (Keuangan Syariah) dalam dekade terakhir ini telah menunjukan perkembangan yang sangat menggem-birakan, hal ini ditunjukan dengan semakin meluasnya jaringan informasi teknologi digital dan komunikasi bidang ekonomi, khususnya ekonomi syariah. Ada dua istilah yang trend dan sering digunakan untuk ekonomi Islam, yaitu ekonomi Syariah dan ekonomi Islam, keduanya menunjuk pada satu asas yang sama, yaitu ekonomi yang didasarkan prinsi syariah (hukum Islam).

Salah satu bentuk pelayanan di bidang ekonomi dan jasa keuangan yang menjadi kebutuhan masyarakat adalah pembiayaan multijasa, yaitu pembiayaan yang diberikan oleh Lembaga Keuangan Syariah (LKS) kepada nasabah dalam memperoleh manfaat atas suatu jasa. 
Jamaluddin, Hasyim Nawawie | Kompleksitas Pembiayaan...

Lembaga Keuangan Syariah (LKS) perlu merespon kebutuhan masyarakat yang berkaitan dengan jasa, agar pelaksanaan transaksi tersebut sesuai dengan prinsip syariah yang dipandang perlu dan penting untuk ditetapkan Fatwa DSN-MUI tentang pembiayaan multijasa untuk dijadikan pedoman masyarakat. ${ }^{1}$

Titik singgung antara ketentuan akad ijarah (ujrah atas manfaat barang dan jasa (ijarat al-a'yan) serta ijarah sewa guna usaha atau pembiayaan dalam penyediaan barang, jasa dan modal. Secara konseptual leasing yang merupakan titik temu antara akad ijarah (sewa-menyewa) dan akad al-ba'i (jual-beli).

Sedangkan dalam hasanah fiqh muamalah maliyyah, akad ijarah dikembangkan menjadi akad Ijarah Muntahiyah Bittamlik (IMBT) dan akad Ijarah Multijasa.

Fiqh muamalah maliyyah sesungguhnya sangat mudah dipahami, karena pendekatanya bersifat praktis (praktik-aplikatif), yang mengkaji tentang berbagai produk fiqh muamalah maliyyah, antara lain : akad pembiayaan ijarah multijasa, dhawabith save deposit box, produk save deposit box, akad perjanjian dan masih banyak akad yang lainya.

Dalam kitab Aqsam al-'Uqud $\boldsymbol{f}$ al-Islam Muhammad Husein Jistaniyah, menyampaikan bahwa pembagian akad baru itu (taqsimat haditsah li al-'uqud), yang meliputi :

1. Akad dari segi terlaksananya akibat hukum akad (al-tanfidz) yang terdiri atas tanfidz seketika (al-jawriyyah) dan tanfidz berjangka waktu (alistimariyyah),

2. Akad dari mustaqil (pokok/al-ashliyyah) dan ikutan/assesoir (altabi'iyyah),

${ }^{1}$ Kodifikasi Produk dan Aktivitas Bank Umum Syariah dan Unit Usaha Syariah (BUS-UUS), (Jakarta: Otoritas Jasa Keuangan (OJK), 2015), hlm. 101-102 
Jamaluddin, Hasyim Nawawie | Kompleksitas Pembiayaan...

3. Akad dari segi bentuknya (al-maudhu') yang terdiri atas akad sederhana (al-'uqud basith) \& akad tergabung (al-'uqud mukhtalath),

4. Akad dari segi karakternya (al-thabi'ah) yang terdiri atas akad almuhaddad dan akad al-ihtimal.

Akad dari segi maudhu' (titel) dibedakan menjadi 2 (dua) akad, 1) akad sederhana (basith), 2) akad campuran (mukhtalath). Muhammad Husein Jistaniyah menyampaikan bahwa makna akad basith adalah sebagai berikut :

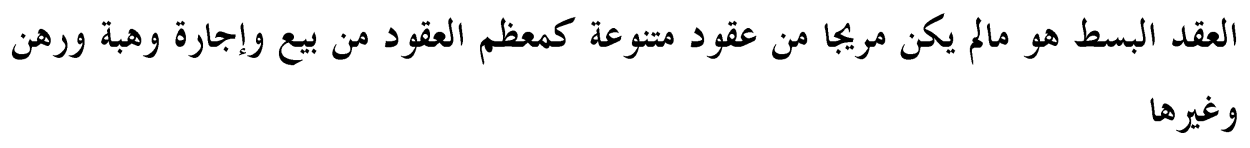

Artinya: "Akad basith adalah akad yang tidak tercampur dengan akad-akad lain yang berkembang, diantaranya akad al-bai' (jual-beli), akad ijarah (sewa-menyewa) dan akad rahn (gadai) “2

Akad basith disebut juga akad tunggal sebagai lawan dari akad murakkab (multiakad) yang merupakan akad ashliyyah dan tabi'iyyah dalam fiqh muamalah maliyyah, diantaranya :

1. Akad jual-beli (akad al-bai'), yaitu akad antara penjual dan pembeli atas sesuatu barang (mabi') serta harga (tsaman) yang dipertukarkan.

2. Akad sewa-menyewa (al-ijarah), yaitu akad antara $\boldsymbol{m} \boldsymbol{u}$ 'jir dan $\boldsymbol{m}$ usta'jir atas manfaat serta ujrah (untuk ijarah ala al-a'yan) atau akad antara ajir dan musta'jir atas manfaat serta ujrah (untuk ijarah ala al-a'mal), yang dipertukarkan.

3. Akad persekutuan/kerjasama usaha (al-muyarakah/stirkah), yaitu akad antara syarik dan syarik (mitra kerja) lainya guna memperoleh keuntungan dari usaha tertentu dengan modal usaha (ra's al-mal) yang

2 Hasan Binti Muhammad Husein Jistaniyah, Aqsam al- 'Uqud fi al-Fiqh al-Islam, (Kerajaan Arab Saudi, jam'iyah Umm al-Qur'an, 1998), hlm. 452. 
Jamaluddin, Hasyim Nawawie | Kompleksitas Pembiayaan...

disatukan dari para syarik dan disepakai nisbah bagi hasil sesuai dengan dasar pembagian keuntungan dan kerugian (nisbah proporsional).

4. Akad perjanjian (kafalah), yaitu akad antara kafil dan makful lah (da'in) yang berupa kesanggupan untuk membayar hutang (dain), makful anhu (madin) dalam hal makful anhu/madin tidak membayar hutangnya kepada makful lah/da'in.

Muhammad Husein J. menyampaikan bahwa makna akad mukhtalath adalah sebagai berikut :

$$
\text { العقد الحتلط هو ما اثثمل على اكثر من عقد واحد امتزجت جميعا فأصبحت عقدا وحدا. }
$$

Artinya: "Akad mukhtalath adalah akad yang terkadang lebih dari satu akad. Semuanya bercampur dan (campuranya tersebut) menjadi satu akad". 3

Para pakar fiqh muamalah maliyyah dalam menjelaskan istilah mukhtalath berbeda-beda makna dan artinya, antara lain :

1. Hanan Binti Muhammad Husein Jistaniyyah, dalam kitab Aqsam al'Uqud fi al-Fiqh al-Islami dan Abdullah Ibrahim al-Musa, dalam kitab al-Syuruth al-Aqdiyyah fi al-Syari'ah al-Islamiyah: Batsul Muqaran Baina al-Syari'ah wa al-Qanun, menyebutkan dengan nama akad Mukhtalath.

2. Syekh Abd. al-Satar Abu Ghaddah, dkk. dalam kitab Asasiyyat alMuamalat wa Masharfiyyah al-Islamiyyah, menyebutkan bahwa tarkib al-'Uqud wa al-Ijtima'uha (mergin contracts).

3. Syekh 'Ala al-Din al-Za'tari, dalam Kitab Fiqh al-Muamalah alMaliyyah al-Muqarin: Shiyaghah Jadidah wa Amtsilah Mu'ashirah, menyebutkan dengan nama ijtima' al- 'uqud.

3 Hasan Binti Muhammad Husein Jistaniyah, Aqsam al- 'Uqud fi al-Fiqh al-Islam, (Kerajaan Arab Saudi, jam'iyah Umm al-Qur'an, 1998), hlm. 451. 
4. Nazih Muhammad membahas topik ini secara khusus yang hasil kajianya diterbitkan dengan judul al-'Uqud al-murakkabah fi al-Fiqh al-Islami, menyebutkan dengan nama al-'Uqud al-Murakkabah (Multiakad). ${ }^{4}$

\section{B. Istimbath Akad Mukhtalat}

Sumber hukum fiqh al-muamalah al-maliyyah sama dengan sumber hukum Islam pada umumnya, baik bidang hukum siyasah (politik), keluarga (ahwal asy-syahriyah), pidana (jinayah), maupun bidang peradilan (murafa'at), yaitu sumbernya al-Qur'an dan al-Hadits yang dipahami dan di kembangkan oleh para ulama melalui proses ijtihad dengan sejumlah pendekatan dan metode, diantaranya qiyas, maslahah mursalah dan urf.

Ada 2 (dua) pendekatan dalam memahami teks-teks al-Qur'an dan al-Hadits terkait dengan fiqh al-muamalah al-maliyyah, yaitu dengan pendekatan tekstual (ta'abudi) dan pendekatan kontekstual (ta'aquli), dengan orientasi sbb:

1. Pendekatan ta'abudi merupakan pendekatan yang menjadikan arti/ makna kebahasaan teks al-Qur'an dan al-Hadits sebagai sumber kebenaran hukum tanpa harus melakukan pendalaman mengenai kausa (illat) yang melatar belakangi timbulnya teks tersebut.

2. Pendekatan ta'aquli merupakan pendekatan yang menjadikan arti/ makna kebahasaan teks al-Qur'an dan al-Hadits sebagai sumber kebenaran dengan tetap melakukan ijtihad guna mendapatkan dan menentukan kausa (illat) hukum yang berada di latarbelakang teks tersebut. $^{5}$

4 Hasan Binti Muhammad Husein Jistaniyah, Aqsam al-'Uqud fi al-Fiqh al-Islam, (KSA, Jam'iyah Umm al-Qur'an, 1998), hlm. 452.

5 Umar Muhammad Sayyid Abd al-Aziz, Ahkam al-Muamalat al-Maliyyah Baina alTa'abbud wa al-Ma'qulliyyah al-Ma'na, (Dubai: Islamic Affairs \& Charitable Activeties Departement, 2010. 
Jamaluddin, Hasyim Nawawie | Kompleksitas Pembiayaan...

Di antara prinsip dalam memahami teks al-Qur'an dan al-Hadits, dalam fiqh muamalah maliyyah adalah prinsip Mura'at al-'Ilal wa al-Mashalih. Prinsip ini antara lain disampaikan oleh al-Syathibi yang menyatakan bahwa ketentuan-ketentuan Allah swt. dan Rarul-Nya yang terdapat dalam al-Qur'an معقولة (المق dan al-Hadits tentang muamalah maliyyah adalah ma'qulat al-ma'na

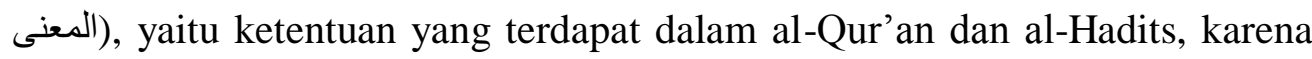
ada sebab illat (illat hukumnya). ${ }^{6}$

Tujuan dari ketentuan syariah terkait dengan fiqh muamalah maliyyah adalah mengambil kemaslahatan (mendapatkan manfaat) dan menolak kemudharatan (جلب المنافع ودرء المفاسد). ${ }^{7}$ Oleh karena itu penera-pan ketentuan fiqh muamalah maliyyah diberlakukan dengan kaidah (الحكم يدور مع علته وجودا (و عدما artinya, "penerapan ketentuan hukum itu selaras dengan 'illat-nya, baik adanya maupun tidak adanya hukum". 8

Dari segi obyeknya, al-ijarah (ujrah \& manfaat/mahal al-manfaat) yang disampaikan para ulama bersifat sederhana (basith) yang belum bersentuhan dengan kompleksitas sewa-menyewa yang tumbuh dan berkembang di kalangan pengusaha. Oleh karena itu sesuai dengan perkembangan peradaban di bidang ekonomi syariah (islam), hukum bisnis syariah dan ekonomi bisnis, akad ijarah yang obyeknya (ma’jur) pada awalnya bersifat sederhana, diubah ke dalam suasana kompleksitas peradaban yang menuntut dibentuknya ijarah multijasa (banyak jasa yang menjadi obyek suatu akad ijarah). ${ }^{9}$

\footnotetext{
${ }^{6}$ Muhammad Ustman Syubair, al-Madkhal ila Fiqh al-Muamalat al-Maliyyat al-Mal al-Milkiyyah al-Aqd, (Ardan: Dari al-Nafa' is, 2009), hlm. 34-38.

7 Abi Ishaq Ibrahim Ibn Musa al-Syathibi, al-Muwafaqat fi Ushul al-Ahkam, vol 1, Jus II, (Bairut: Dar al-Fikr, 1341 H.), hlm.268

8 Muhammad ibn Shalih al-Utsaimin, al-Qawa'id al-Fiqhiyah, (Iskandariyah: Dar alBashirah, 1422 H), hlm. 39.

9 Jaih Mubarok \& Hasanudin, Fiqh Muamalah Maliyyah: Akad Ijarah \& Ju'alah, (Bandung: Simbiosa Rekatama Media, 2017), hlm. 215-216.
} 
Jamaluddin, Hasyim Nawawie | Kompleksitas Pembiayaan...

Ada 2 (dua) akad ijarah dalam dua domain yang berbeda : 1) akad ijarah dalam produk Lembaga Keuangan Syariah (LKS) yang bernama Save Deposit Box (SDB) yang termasuk domain akad ijarah yang sederhana, 2) ijarah multijasa yang masuk dalam domain akad ijarah yang kompleks (multiakad).

Dalam fatwa Dewan Syariah Nasional Majelis Ulama Indonesia (DSNMUI) Nomor 24 Tahun 2002 tentang Save Deposit Box (SDB) merupakan respons terhadap permohonan Lembaga Keuangan Syariah (LKS) berdasarkan surat Direksi Bank Syariah Mandiri Nomor : 3/37/ DDP tertanggal 31 Agustus 2001 tentang permohanan fatwa untuk layanan Save Deposit Box (SDB).

Secara teoritis menyatakan bahwa tidak terdapat definisi Save Deposit Box (SDB), tetapi secara sosiologis praktis menyatakan bahwa Save Deposit Box (SDB) merupakan salah satu produl jasa perbankan syariah yang berupa penyediaan tempat penyimpanan barang berharga, dengan ketentuan sebagai berikut :

1. Save Deposit Box (SDB) harus dilakukan dengan Akad Ijarah,

2. Syarat dan rukun ijarah merujuk kepada fatwa DSN-MUI Nomor : 9/ DSN-MUI/IV/2000 tentang Pembiayaan Ijarah,

3. Barang yang disimpan adalah barang yang berharga, tidak haram dan diharamkan serta tidak dilarang oleh Negara,

4. Besar biaya ijarah (sewa) ditetapkan berdasarkan kesepakatan kedua belah pihak, 
Jamaluddin, Hasyim Nawawie | Kompleksitas Pembiayaan...

5. Hak dan kewajiban pemberi sewa-penyewa ditentukan berdasarkan kesepakatan, sepanjang tidak bertentangan rukun dan syarat Akad Ijarah. $^{10}$

Pembiayaan akad ijarah multijasa hukumnya boleh (ja iz) dengan menggunakan akad Ijarah dan/atau Kafalah. Dalam hal Lembaga Keuangan Syariah (LKS) menggunakan akad ijarah, maka harus mengikuti semua ketentuan yang ada dalam Fatwa DSN-MUI tentang akad Ijarah.

Demikian juga apabila Lembaga Keuangan Syariah (LKS) menggunakan akad Kafalah, maka harus mengikuti semua ketentuan yang ada dalam Fatwa DSN-MUI tentang Kafalah.

Dalam kedua pembiayaan multijasa tersebut di atas, Lembaga Keuangan Syariah (LKS) dapat memperoleh imbalan jasa (ujrah) atau fee. Besaran ujrah atau fee harus disepakati di awal dan dinyata-kan dalam bentuk nominal (bukan dalam bentuk prosentase).

\section{Pengertian Dhawabith, SDB \& Akad Ijarah Multijasa \\ 1. Dhawabith}

Sebelum membahas pengertian al-dhawabith atau al-dhawabith fiqhiyah, yang berkaitan dengan jual-beli, sewa-menyewa \& ijarah bil ujrah, maka ada baiknya penulis bahas dahulu bangunan dasar kaidah fiqhiyah terlebih dahulu. Pengertiah kaidah fiqh (qawaid al-fiqhiyyah) banyak di definisikan oleh para ulama ahli ushul, sbb :

$$
\text { قضية كلية ينطبق حكمها على الجزءئيات تندرج تحتها }
$$

Artinya : "Segala sesuatu (yang berimplikasi hukum) yang bersifat umum yang mencakup atas bagian-bagianya"."

10 Fatwa Dewan Syariah Nasional Majelis Ulama Indonesi (DSN-MUI) Nomor 24 Tahun 2002 ttg. Save Deposit Box, (Jakarta: Majelis Ulama Indonesi, 2002), hlm. 216.

11 Khalid Ramadhan Hasan, Mu'jam Ushul al-Fiqh al-Rawdhah, tt.), hlm.219 
Wahbah al-Zuhayli memberikan definisi tentang kaidah hukum yang bersifat global (umum), sebagai berikut :

$$
\text { الضو ابط الكية العامة التى تثنمل على احكام جزئية }
$$

Artinya : "Dhawabith yang bersifat global dan umum yang mencakup atas hukum-hukum itu bersifat parsial (juz'iyah)". ${ }^{12}$

Contoh dari kaidah umum (global) adalah segala perintah bersifat (menunjukkan) pada wajib (kewajiban). Demikian pula dengan segala larangan bersifat (menunjukkan) tidak boleh atau haram (keharaman).

Pengertian yang lain diungkapkan oleh Izzat Abid al-Da'us yang lebih (sangat) sederhana, sbb :

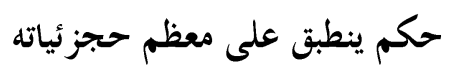

Artinya : "Hukum yang mencakup atas sebagian besar bagian-bagianya (juz'iyahnya)". 13

Contoh dari pengertian ini adalah kaidah asasi, yaitu kaidah-kaidah fiqh yang lima (qawa'id al-khamsah) berikut cabang-cabangnya.

Dari uraian di atas dapat penulis simpulkan (sementara) bahwa kaidahkaidah fiqh salah satu bangunan dasar (asas) dari segala macam kaidah yang berhubungan dengan masalah fiqh, yang diolah dan bersumber dari alQur'an, al-Hadits, al-Ijma' dan al-Qiyas, baik dari para sahabat, tabi'in, dan para ulama salaf, berdasarkan kasus-kasus aktual yang dibutuhkan dalam menetapkan suatu hukum, sehingga melahirkan landasan teoritik dalam menetapkan suatu hukum (istinbath al-hukm).

12 Wahbah al-Zauhayli, al-Wajiz fi Ushul al-Fiqh, (Damaskus: Dar al-Fikri, Cet I, 1419 H/1999 M.), hlm. 13

${ }^{13}$ Izzat Abid al-Da'us, al-Qwaid al-Fiqhiyyah, (Damaskus: Dar al-Tirmidzi, Cet. III, 1409 H/1989 M.), hlm. 7 
Jamaluddin, Hasyim Nawawie | Kompleksitas Pembiayaan...

Al-Qawaid al-Fiqhiyyah (kaidah-kaidah fiqh) yang telah penulis uraikan di atas, dikenal juga al-dhawabith al-fiqhiyyah. Secara bahasa bentuk jamak dari dhabith, dari akar kata $\boldsymbol{d h}$ - $\boldsymbol{b}$-th . Kata ini merujuk pada pengertian luzum al-syai wa habsuhu, tetap dan bertahanya sesuatu, sesuatu yang terkait dan terjaga (hifdzuhu bi al-hazmi). ${ }^{14}$

\section{Save Depost Box}

Save deposit box adalah konsep yang selaras dengan dhawabit fiqh muamalah maliyah. Save deposit box merupakan pengembangan konsep mahal al-manfaat, karena konsep dasar perjanjian akad ijarah adalah perjanian jual-beli, maka berlaku ketentuan jual-beli, misalnya, penjual tidak boleh menjual barang orang lain yang bukan haknya/miliknya (al-bai' ma laisa indak). Oleh karena itu, save deposit box harus milik Lembaga Keuangan Syariah (LKS) sebelum manfaatnya dijual kepada pihak lain, dikuasai oleh Lembaga Keuangan Syariah (LKS) (konsep al-qabdh), penguasaan dan manfaat tersebut dapat diserahterimakan (konsep taslim almabi’ taslim al-manfaat). ${ }^{15}$

\section{Akad}

Dalam bahasa Indonesia, diksi akad ( $\boldsymbol{a l}$-Aqd) sering diterjemahkan menjadi perjanjian. Semenatara dalam literatur fiqh muamalah maliyyah, dibedakan secara tegas antara janji (al-wa'd) dan perjanian (al-aqd). Dalam bentuknya terkadang, janji hampir mirip dengan akad, terutama pada saat saling berjanji (al-muwa'adah).

Secara harfiah (bahasa), akad adalah al-rabth (ikatan) al-tahakkum (mengokohkan/meratifikasi) dan persetujuan atau kesepakatan (al-ittifaq).

${ }^{14}$ Ibrahim Musthafa, et.All, al-Mu'jam Al-Wasith, (Kerajaan Saudi Arabiyah: Dar alDakwah, tt. Jus 1), hlm.533.

15 Jaih Mubarok \& Hasanudin, Fiqh Muamalah Maliyyah: Akad Ijarah \& Ju'alah, (Bandung: Simbiosa Rekatama Media, 2017), hlm. 217. 
Sedangkan secara istilah, akad adalah pertalian/perpautan antara pernyataan kehendak dari satu pihak (ijab) dan pernyataan permintaan/persetujuan dari pihak lain (qabul) yang berpengaruh terhadap obyek akad (ma'qud alaih). ${ }^{16}$

Secara definitif akad dalam pengertian khusus, patut dicermati uraian sebagai berikut :

Secara implisit menunjukkan bahwa ada dua pihak yang melakukan akad, 1) pihak yang melakukan penawaran (al-ijab), 2) pihak yang menyatakan persetujuan (al-qabul). Ijab dan qabul merupakan aspek nyata dari kehendak (iradah) yang bersifat abstrak. Hal ini seara tidak langsung menunjukkan bahwa syarat sahnya akad dari pihak yang melakukanya (aqid/subyek hukum) harus berbilang (ta'addud/ ta'addud al-aqidin). Dengan kata lain, akad pada dasarnya tidak dapat dilakukan hanya oleh satu pihak, tetapi harus dilakukan oleh banyak pihak, karena pihak yang berakad merupakan syarat yang bersifat umum (lex generalis), yang juga memiliki pengecualian al-mustatsnayat yang disebut juga (lex spesialis).

Akad-akad yang termasuk akad tijari (bisnis), baik yang mu'awadhat (bersifat pertukaran) maupun ghairu mu'awadhat (bukan akad pertukaran). Sedangkan di antara akad-akad yang dapat dilakukan secara mandiri (subyek hukumnya) tunggal (tidak berbilang), ${ }^{17}$.

Dengan demikian jenis akad yang sifatnya mandiri adalah akad :

a. Ju'alah (akad ju'alah), yaitu komitmen dari ja'il kepada maj'ul untuk memberikan imbalan (ju'l) dalam jumlah tertentu kepada pihak lain yang mencapai kondisi atau hasil tertentu (natijah) karena tindakan yang dilakukan.

16 Ali Syekh 'Ala al-Din al-Za'tari, Fiqh al-Muamalat Maliyah al-Muqaran: Shiyaghah Jadidah wa Amtsilah Mu'ashirah, (Damaskus: Dar al-Ashma' 2008), hlm. 7-9.

17 Wahbah Zuhaily, al-Fiqh al-Islami wa Adilatuh, Juz 4, (Libanon: Dar al-Fikr, 2006), hlm. 2.921. 
Jamaluddin, Hasyim Nawawie | Kompleksitas Pembiayaan...

b. Waqaf, secara bahasa berasal dari kata waqafa yang berarti habasa (menahan), dan al-man'u (mencegah/menghalangi), yaitu pemisahan harta dari wakif untuk didayagunakan (termasuk di investasikan oleh pihak nadzir) agar mendatangkan penghasilan/ sesuatu nilai, baik berupa margin/keuntungan (ribhun), bagi hasil (bagi akad syirkah \& akad mudharabah), maupun ujrah (dalam akad ijarah). Keuntungan tersebut di sedekahkan kepada pihak penerima yang ditunjuk (mauquf alaih). Dalam kitab-kitab fiqh klasik, wakaf tidak disebut akad, akan tetapi ikrar wakaf (pernyataan), termasuk dalam Peraturan Pemerintah Nomor 25 Tahun 1977 tentang Perwakafan Tanah Milik, Kompilasi Hukum Islam, Inpres Nomor 1 Tahun 1998, UU Nomor 41 Tahun 2004 tentang Wakaf dan PP Nomor 42 Tahun 2006 tentang Pelaksanaan UU Nomor 41 Tahun 2004 tentang Wakaf.

c. Ibra' (pelepasan hak), di antaranya pernyataan dari da'in (pihak yang memiliki piutang (al-dain) untuk membebaskan madin (pihak yang memiliki utang) dari kewajiban membayar utangnya. al-ibra' sering kali disebut istqath al-haqq dan tanazul al-haqq.

d. Thalaq, yaitu seorang suami yang menceraikan istrinya pada dasarnya tidak memerlukan persetujuan adri istri dan/atau istri-istri yang dicerainya, akan tetapi di indonesia berlaku undang-undang nomor 1 tahun 1974 yang mengatur bahwa cerai wajid dilakukan di pengadilan dalam lingkungan peradilan agama

e. Yamin (sumpah dan termasuk nadzar), yaitu pernyataan secara sepihak dari seseorang yang mewajibkan dirinya sendiri, apabila kondisi yang diinginkan tercapai, misalnya seseorang bernadzar akan pergi umroh apabila gaji sertifikasi dosen cair tahun 2021. Hal ini sejalan dengan pendapat Qadhi Syuraih ibn al-Harits yang mengatakan bahwa : 


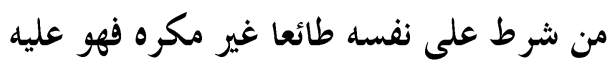

Artinya: "Barang siapa yang membebankan sesuatu kepada dirinya secara sukarela tanpa ada paksaan, maka sesuatu itu wajib dilaksanakan". ${ }^{18}$

Di dalam kitab Hasyiyah al-Dasuki ala al-Syarh al-Kabir dijelaskan pendapat al-Dasuki yang mengatakan bahwa :

$$
\text { من التز معروفا لزمه }
$$

Artinya: "Barang siapa yang berkomitmen melaksanakan suatu kebaikan, maka ia wajib melaksanakanya (menunaikanya) " 19

f. Kafalah (aqd al-kafalah), yaitu penjaminan dari satu pihak, karena adanya kesanggupan untuk melaksanakan tindakan hukum tertentu, baik yang berkaitan dengan harta (kafalah bi al-mal) maupun yang berkaitan dengan kewajiban menghadirkan orang (kafalah bi al-nafs).

g. Washiyah (wasiat), yaitu komitmen dari satu pihak kepada pihak lain untuk menghibahkan harta miliknya, apabila pihak yang berkomit- men meninggal dunia. Pada prinsipnya wasiat termasuk akad hibah yang keterlaksanaan akibat hukumnya bergantung pada umur (hidup dan matinya) pihak yang berkomitmen.

\section{Ijarah Multijasa}

Kata ijarah berasal dari istilah al-ajru, yang berarti al-iwadh (upah/ganti). ${ }^{20}$ Wahbah Zuhaily menjelaskan bahwa ijarah menurut bahasa bai' al-manfaah, yang berarti jual-beli manfaat. ${ }^{21}$

18 Athiyyah Adlan Athiyyah Ramadhan, Mausu'ah al-Qawa'id al-Fiqhiyyah, (Iskandariyyah: Dar al-Aiman, 2007), hlm. 89

19 Ali Ahmad al-Nadawi, al-Qawa'idul al-Fiqhiyyah, cet. ke 3, (Damaskus: Dar alQalam, 1994), hlm. 93 


\section{Jamaluddin, Hasyim Nawawie | Kompleksitas Pembiayaan...}

Sementara, pengertian ijarah menurut istilah sebagai berikut :

$$
\text { عقد لازم على منفعة, مدة معلومة, بثمن معلوم. }
$$

Artinya: "Akad yang lazim atas suatu manfaat pada waktu tertentu dengan harga tertentu". 22

Di dalam al-Qur'an surat al-Baqarah ayat 233 dijelaskan tentang ujrah/upah/jasa sbb :

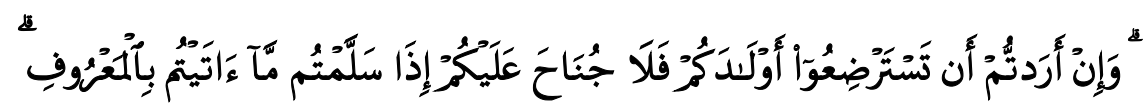

Terjemahnya: "Dan jika kamu ingin anakmu disusukan oleh orang lain, maka tidak ada dosa/boleh bagimu apabila kamu memberikan upah/ujrah/jasa (bayaran) yang sesuai dengan jasanya dan yang pantas sesuai dengan situasi dan kondisi setempat (patut). bertakwalah kamu kepada Allah dan ketahuilah bahwa Allah Maha melihat apa yang kamu kerjakan". ${ }^{23}$ (QS. al-Baqarah, 233).

Di dalam al-hadits Nabi Muhammad saw. dijelaskan tentang ujrah/upah/jasa sbb :

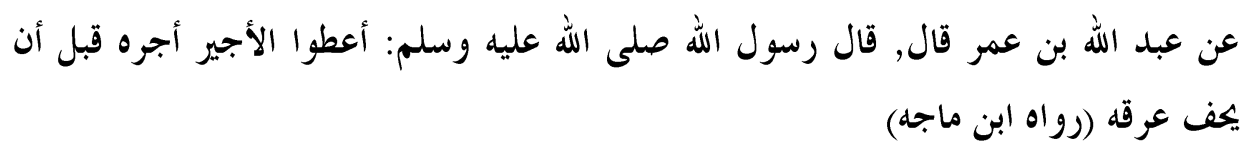

Artinya: "Diriwayatkan dari Abdullah ibn Umar, ia mengatakan bahwa Rasulullah saw. berkata: berikankan upahnya kepada orang yang bersangkutan, sebelum keringatnya kering", 24 (HR. ibnu Majah).

${ }^{20}$ Ali Jum'ah Muhammad, dkk. Mausu'ah Fatawa al-Muamalah Maliyah Lilmasharif wa al-Muassasat al-Maliyah al-Islamiyah, al-Ijrah, Jilid 4, (Kairo: Dar al-Salam Liltahaba'ah wa- al-Tauzi' al-Tarjamah, 2008), hlm. 19.

21 Wahbah Zuhaily, al-Fiqh al-Islami wa Adilatuh, Juz 4, (Libanon: Dar al-Fikr, 1984), hlm. 732

${ }^{22}$ Ali Jum'ah Muhammad, dkk. Mausu'ah Fatawa al-Muamalah Maliyah Lilmasharif wa al-Muassasat al-Maliyah al-Islamiyah, al-Ijrah.

${ }^{23}$ Departemen Agama RI, al-Qur'an dan Terjemahnya, (Jakarta: Proyek Pengadaan Kitab Suci al-Qur'an, 1984), hlm. 57

${ }^{24}$ Abu Abdullah Muhammad bin Yazid al-Qazuwaini wa Majah, Sunan Ibnu Majah, jaz 7, (Kairo: Mawqi' Wazirah al-Auqaf al-Mishriyah, t. th.), hlm. 398, (hadits ke 2537). 
Ijarah menurut madzhab Hanafiyah, Malikiyah dan Syafi'iyah secara subtansial (inti pointnya) orientasinya tentang akad adalah sama, sedangkan secara singkat madzhab Hanafiyah berpendapat, bahwa akad itu sbb :

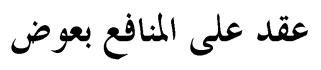

Artinya: "Akad terdapat suatu manfaat dengan adanya ganti". 25

Berdasarkan orientasi al-Qur'an, al-Hadits dan beberapa pendapat para ulama madzhab dan ijma' para ulama tentang kebolehan akad ijarah, karena manusia senantiasa membutuhkan manfaat dari suatu barang atau tenaga orang lain.

Ijarah adalah salah satu bentuk aktivitas yang dibutuhkan oleh manusia, karana tidak ada kemampuan untuk memenuhi kebutuhan hidupnya, kecuali dengan melalui sewa-menyewa, upah-mengupah terlebih dahulu. Transaksi ini perlu, penting dan berguna untuk meringankan kesulitan yang dihadapi oleh manusia dan termasuk salah satu bentuk aplikasi tolong menolong yang dianjurkan oleh agama.

Ijarah merupakan bentuk muamalah, oleh karena itu syariat islam mendelegasikan eksistensinya (keberadaanya). Konsep ijarah merupakan manifestasi keluwesan hukum islam untuk menghilangkan kesulitan dalam kehidupan manusia. ${ }^{26}$

Obyek ijarah berupa manfaat suatu benda maupun tenaga manusia dibagi menjadi 2 (dua) bentuk :

1. Ijarah Aini, yaitu ijarah yang berhubungan dengan penyewaan benda, yang tujuanya untuk mengambil manfaat dari benda tersebut tanpa harus memindahkan kepemilikan benda tersebut, baik benda bergerak, seperti

${ }^{25}$ Wahbah Zuhaily, al-Fiqh al-Islami wa Adilatuh.

26 Rozalinda, Fiqh Ekonomi Syariah, Prinsip dan Implementasinya pada Sektor Keuangan Syariah, (Jakarta: PT RajaGrafindo Persada, 2016), hlm. 131. 


\section{Jamaluddin, Hasyim Nawawie | Kompleksitas Pembiayaan...}

meyewa kendaraan mobil, sepeda motor maupun bentuk kendaraan lainya, serta benda yang tidak bergerak seperti sewa gedung, rumah, sawah/tanah, dan lain-lain.

2. Ijarah Amali, yaitu ijarah terhadap perbuatan (tenaga) manusia yang diistilahkan dengan sistem upah-mengupah. Ijarah ini digunakan untuk memperoleh jasa dari seseorang dengan membayar upah (jasa) dari pekerjaan yang dilakukan. $^{27}$

Upah/imbalan berupa benda yang diketahui yang dibolehkan memanfaatkanya (mal mutaqawwim), sesuai hadits Nabi Muhammad saw. sbb :

$$
\text { عن ابى هريرة وابى سعيد قالا من استأجرا جيرا فليعلمه اجره (رواه ابى هريرة وابى سيعد) }
$$

Artinya: "Dari Abu Hurairah dan Abu Said keduanya berkata: barang siapa yang melakukan upah-mengupah, maka hendaknya dapat diketahui upahnya "di depan" 28 (HR. Abu Hurairah \& Abu Said).

Seiring dengan berkembangnya kebutuhan transaksi \& perubahan gaya hidup di masyarakat, maka kini berkembang pula berbagai jenis pelayanan yang diberikan bank syariah yang dikenal sebagai pembiayaan multijasa (fee based service).

Pembiayaan multijasa (fee based service) di perbank Syariah mempunyai beragam layanan yang meliputi transaksi pengirimaan uang, Sharf (jual beli valuta asing), penerbitan Letter of Credit (L/C), gadai (Rahn), take over pembiayaan (factoring), garansi bank, termasuk layanan transaksi kartu kredit syariah untuk dapat memenuhi kebutuhan gaya hidup modern yang serba canggih, cepat dan efisien.

27 Ali Haidar, Durar al-Hukkam Syarah Majallah al-Ahkam, Jilid 1, (Bairut: Dar alKutub al-Ilmiah, t. th), hlm. 382

28 Abu Bakar Abdullah ibn Muhammad ibn Abi Syaibah, al-Kufi al Mushannif fi alHadits wa al-Atsar, (Riyadh al-Maktabah al-Rusy, Juz 4, 14090), hlm. 366 (Hadits ke 21109). 
Pada prinsipnya layanan multijasa perbankan syariah mengacu pada konsep Ijarah (Ujrah), yaitu pembayaran atas suatu jasa. Berbeda dengan akad musyarakah dan mudharabah yang menggunakan pembagian nisbah dalam bentuk prosentase, dalam pembiayaan multijasa ini, bank syariah akan menetapkan ujrah langsung dalam bentuk rupiah.

Kata Ijarah berasal dari kata $\boldsymbol{a l}$-Ajru yang menurut bahasanya adalah al-iwadh yang mempunyai arti ganti atau upah. Secara etimologi ijarah berarti upah, jasa dan imbalan. Menurut terminologi ijarah adalah akad pemindahan hak guna (manfaat) atas suatu barang atau jasa dalam waktu tertentu dengan pembayaran upah sewa tanpa diikuti oleh pemindahan kepemilikan atas barang itu sendiri. ${ }^{29}$

Ijarah Multijasa dikembangkan di Indonesia setelah diterbitkanya Fatwa Dewan Syariah Nasional Majelis Ulama Indonesi (DSN-MUI) Nomor 44 Tahun 2004 tanggal 28 April 2004 tentang pembiayaan Ijarah Multijasa. Dalam fatwa tersebut tidak terdapat definisi operasional pembiayaan multijasa, akan tetapi secara implisit (tersirat), terlihat dalam pertimbangan sosiologisnya bahwa pembiayaan multijasa adalah pem-biayaan yang diberikan oleh Lembaga Keuangan Syariah (LKS) kepada nasabah dalam memperoleh manfaat atas suatu jasa.

Pembiayaan multijasa merupakan fatwa yang dibentuk dalam alur dua madzhab pemikiran, yaitu : 1) madzhab pembiayaan, 2) madzhab akad. Dalam pandangan madzhab pembiayaan, pembiayaan multijasa adalah penyediaan dana (tagihan) atau yang dipersamakan dengan itu, berupa transaksi multijasa dengan menggunakan akad ijarah ber- dasarkan kesepakatan antara bank dan nasabah yang mewajibkan nasabah melunasi kewajibanya sesuai dengan akad.

29 Jaih Mubarok \& Hasanudin, Fiqh Muamalah Maliyyah: Akad Ijarah \& Ju'alah, hlm. 219. 
Jamaluddin, Hasyim Nawawie | Kompleksitas Pembiayaan...

Dalam pandangan teori madzhab akad, ijarah multijasa pada prinsipnya merupakan pengembangan akad ijarah, baik ijarah atas barang (sewa-menyewa) maupun ijarah atas orang (buru kerja/jasa) serta terkoneksi dengan akad lainya, karena ragam obyek yang diterima oleh nasabah berbeda-beda. Ijarah multijasa merupakan bagian dari konsep multiakad (aluqud al-murakkabah) bahkan melampui konsep tersebut.

Fatwa DSN-MUI Monor 44 tahun 2004 tentang Pembiayaan Ijarah Multijasa dalam bentuk produk perjalanan ibadah haji. dalam pelak-sanaan ibadah haji terdapat banyak banyak obyek, setidaknya terdapat dua akad yang digunakan, yaitu akad ijarah dan akad jual-beli. Obyek yang dibiayai dalam perjalanan ibadah haji, dapat dilihat tabel berikut :

Tabel : Ijarah Multijasa Ibadah Haji \& Umroh

\begin{tabular}{|l|l|l|l|}
\hline No & \multicolumn{1}{|c|}{ Obyek Akad } & \multicolumn{1}{c|}{ Akad } & \multicolumn{1}{c|}{ Keterangan } \\
\hline 01 & Visa (Izin Kunjungan/Tinggal) & Ijarah & Lokal Daerah/Wil. \\
\hline 02 & Bimbingan Praktek Ibadah Haji & Ijarah & Lokal Daerah/Wil. \\
\hline 03 & Buku Bimbingan Ibadah Haji \& Doa & $\begin{array}{l}\text { Jual- } \\
\text { Beli }\end{array}$ & Percetakan buku \\
\hline 04 & Transportasi Darat dalam Negeri & Ijarah & PT Aotobus \\
\hline 05 & Transportasi Udara & Ijarah & PT Girgantara \\
\hline 06 & Pembimbing (Muthawwif) & Ijarah & Luar Negeri \\
\hline 07 & Konsumsi (Makan-Minum) & $\begin{array}{l}\text { Jual- } \\
\text { Beli }\end{array}$ & Dalam \& Luar Negeri \\
\hline 08 & Pemondokan (Hotel) & Ijarah & Luar Negeri \\
\hline 09 & Transportasi Darat Luar Negeri & Ijarah & Dalam \& Luar Negeri \\
\hline & & & \\
\hline
\end{tabular}


Jamaluddin, Hasyim Nawawie | Kompleksitas Pembiayaan...

\begin{tabular}{|l|l|l|l|}
\hline 10 & Layanan Kesehatan \& PPPK & Ijarah & Dalam \& Luar Negeri \\
\hline 11 & Baju Haji, Koper, Tas Jinjing dll. & Jual-beli & Dalam \& Luar Negeri \\
\hline
\end{tabular}

Dalam tabel di atas nampak bahwa dalam ijarah multijasa terdapat multiobyek dan multiakad (setidaknya ada dua akad). Dari 11 (sebelas) obyek yang merupakan bagian dari penyelenggaraan ibadah haji, terdapat 11 obyek yang layak menggunakan akad ijarah, baik atas barang dan jasa, seperti transportasi darat dan udara serta pemondokan.

Sedangkan dua lainya layak menggunakan akad jual-beli (makan, minum, buku bimbingan ibada Haji dan Umroh).

Mengapa istilah yang digunakan menggunakan istilah ijarah multijasa, tidak menggunakan istilah akad jual-beli. Secara akademis terdapat pilihan akad yang memungkinkan digunakan, yaitu akad ijarah dan akad jual-beli. Sedangkan dari ilmu pengetahuan dan praktik bisnis, pembiayaan ibadah haji bisa diubah menjadi paket haji, sehingga dapat diperjual-belikan (jual-beli paket haji). Akan tetapi dari segi orientasi perincian obyek dicakup (cakupanya) menggunakan akad yang relevan, lebih tepat menggunakan istilah ijarah multijasa, karena kebanyakan obyeknya lebih tepat menggunakan istilah akad ijarah multijasa .

\section{Implementasi Ijarah Multijasa}

Maskanul Hakim (Badan Pelaksanan Harian DSN-MUI) menjelas-kan bahwa pembiayaan ijarah multijasa secara komprehensif dan strategi implementasinya dapat dilakukan oleh Lembaga Keuangan Syariah (LKS). Fatwa \& produk ijarah multijasa terbentuk karena adanya permintaan dari Lembaga Keuangan Syariah (LKS) untuk mengem-bangkan produk pembiayaan syariah pada 3 (tiga) macam keperluan : 1) pembiayaan pernikahan, 2) pembiayaan wisata ibadah (umroh dan haji), 3) pembiayaan 


\section{Jamaluddin, Hasyim Nawawie | Kompleksitas Pembiayaan...}

pendidikan sekolah, studi lanjutan (kuliah), bahkan dalam perkembangnya bermutasi menjadi produk multiguna sebagaiman sudah dijelaskan, bahkan di daeran pedesaan, produk ini digunakan untuk pengurusan dan pembiayaan yang akan berangkat ke luar negeri (TK, TKW), dan lain-lain.

Produk multijasa idealnya dilaksanan sebagaimana pembiayaan ijarah. Pihak bank membeli/menyewa aset dan menyewakanya kepada nasabah, kemudian masabah menyewa secara cicilan (mengangsur) kepada bank. Itulan fungsi ijarah multijasa yang sesungguhnya dari fungsi intermediary institutions sebagaimana bank pada umumnya.

Produk bank syariah itu banyak ragam dan jenisnya serta mudah dilaksanakan, karena seirama dan sejalan dengan transaksi di sektor riil. Kiat untuk menjalankan ijarah multijasa denga baik, benar dan aman dari dari sisi syariahnya adalah mendorong kepada bank untuk menciptakan kerjasama dengan penyedia tenaga dan jasa serta lembaga penyedia jasa, seperti sekolah, rumah sakit, agen perjalanan umroh dan haji, perusahaan, sehingga akan terbentuk fungsi komersial yang seimbang dengan misi pengembangan masyarakatnya, meskipun ada sebagian ulama yang keberatan pembelian jasa tenaga pendidikan.

Imam Abu Hanifah memberikan pendapat bahwa hampir semua jasa diperbolehkan selama benar, baik, halal dan thayyib. ${ }^{30}$

\section{Kesimpulan}

Dari uraian dan jabaran di atas, maka dapat penulis simpulkan bahwa Kompleksitas Pembiayaan Ijarah Multijasa dalam Fatwa Dewan Syari'ah Nasional Nomor 44/2004 Perspektif Fiqh Muamalah Maliyyah sbb :

30 Ajeng Ar'atus Solihah, Penerapan Akad Ijarah pada Pembiayan Multijasa dalam Perspektif Hukum Islam, dalam az-Zarqa, vol. 6 Nomor 1 Juni 2014, hlm. 103. 
Ekonomi Islam (keuangan syariah) keduanya menunjuk pada satu asas yang sama, yaitu ekonomi yang didasarkan prinsip syariah (hukum Islam).

Lembaga Keuangan Syariah perlu merespon kebutuhan masyarakat yang berkaitan dengan jasa, agar pelaksanaan transaksi tersebut sesuai dengan prinsip syariah yang dipandang perlu untuk ditetapkan Fatwa DSNMUI tentang pembiayaan multijasa untuk dijadikan pedoman masyarakat.

Titik singgung antara ketentuan akad ijarah (ujrah atas manfaat barang dan jasa (ijarat al-a'yan) dan ijarah sewa guna usaha (pembiayaan dalam penyediaan barang, jasa dan modal). Secara konseptual leasing yang merupakan titik temu antara akad ijarah (sewa-menyewa) dan akad al-ba'i (jual-beli).

Produk multijasa idealnya dilaksanan sebagaimana pembiayaan ijarah. Pihak bank membeli/menyewa aset dan menyewakanya kepada nasabah, kemudian masabah menyewa secara cicilan (mengangsur) kepada bank. Itulan fungsi ijarah multijasa yang sesungguhnya dari fungsi intermediary institutions sebagaimana bank pada umumnya

\section{Daftar Pustaka}

Abd al-Aziz, Umar Muhammad Sayyid, Ahkam al-Muamalat al-Maliyyah Baina al-Ta'abbud wa al-Ma'qulliyyah al-Ma'na, (Dubai: Islamic Affairs \& Charitable Activeties Departement, 2010.

Abi Syaibah, Abu Bakar Abdullah ibn Muhammad ibn, al-Kufi al Mushannif fi al-Hadits wa al-Atsar, Riyadh: al-Maktabah al-Rusy, Juz 4, 1409.

al-Da'us, Izzat Abid, al-Qwaid al-Fiqhiyyah, (Damaskus: Dar al-Tirmidzi, Cet. III, 1409 H/1989 M.

al-Nadawi, Ali Ahmad, al-Qawa'idul al-Fiqhiyyah, cet. ke 3, Damaskus: Dar al-Qalam, 1994. 
Jamaluddin, Hasyim Nawawie | Kompleksitas Pembiayaan...

al-Qazuwaini wa Majah, Abu Abdullah Muhammad bin Yazid, Sunan Ibnu Majah, Juz 7, Kairo: Mawqi’ Wazirah al-Auqaf al-Mishriyah, t. th.

al-Syathibi, Abi Ishaq Ibrahim Ibn Musa, al-Muwafaqat fi Ushul al-Ahkam, Vol. 1, Jus II, Bairut: Dar al-Fikr, 1341 H.

al-Za'tari, Ali Syekh 'Ala al-Din, Fiqh al-Muamalat Maliyah al-Muqaran: Shiyaghah Jadidah wa Amtsilah Mu'ashirah, Damaskus: Dar alAshma' 2008.

al-Zuhaily, Wahbah, al-Wajiz fi Ushul al-Fiqh, Damaskus: Dar al-Fikri, Cet I, 1419 H/1999 M.

Fikr, 2006.

Departemen Agama RI., al-Qur'an dan Terjemahnya, (Jakarta: Proyek Pengadaan Kitab Suci al-Qur'an, 1984.

Fatwa Dewan Syariah Nasional Majelis Ulama Indonesi (DSN-MUI) Nomor: 24 Tahun 2002 ttg. Save Deposit Box, Jakarta: Majelis Ulama Indonesi, 2002.

Haidar, Ali, Durar al-Hukkam Syarah Majallah al-Ahkam, Jilid 1, Bairut: Dar al-Kutub al-Ilmiah, t. th.

Hasan, Khalid Ramadhan, Mu'jam Ushul al-Fiqh al-Rawdhah, tt.

Jistaniyah, Hasan Binti Muhammad Husein, Aqsam al- 'Uqud fi al-Fiqh alIslam, Kerajaan Arab Saudi, Jam'iyah Umm al-Qur’an, 1998.

Kodifikasi Produk dan Aktivitas Bank Umum Syariah dan Unit Usaha Syariah (BUS-UUS), Jakarta: Otoritas Jasa Keuangan (OJK), 2015.

Mubarok, Jaih \& Hasanudin, Fiqh Muamalah Maliyyah: Akad Ijarah \& Ju'alah, Bandung: Simbiosa Rekatama Media, 2017.

Muhammad, Ali Jum'ah, dkk. Mausu'ah Fatawa al-Muamalah Maliyah Lilmasharif wa al-Muassasat al-Maliyah al-Islamiyah, al-Ijrah, Jilid 4, (Kairo: Dar al-Salam Liltahaba'ah wa- al-Tauzi' al-Tarjamah, 2008. 
Jamaluddin, Hasyim Nawawie | Kompleksitas Pembiayaan...

Musthafa, Ibrahim, et.all, al-Mu'jam al-Wasith, Juz 1, Kerajaan Saudi Arabiyah: Dar al-Dakwah, t.th.

Ramadhan, Athiyyah Adlan Athiyyah, Mausu'ah al-Qawa'id al-Fiqhiyyah, Iskandariyyah: Dar al-Aiman, 2007.

Rozalinda, Fiqh Ekonomi Syariah: Prinsip dan Implementasinya pada Sektor Keuangan Syariah, Jakarta: PT RajaGrafindo Persada, 2016.

Solihah, Ajeng Mar'atus, Penerapan Akad Ijarah pada Pembiayan Multijasa dalam Perspektif Hukum Islam, dalam az-Zarqa, vol. 6 Nomor 1 Juni 2014.

Syubair, Muhammad Ustman, al-Madkhal ila Fiqh al-Muamalat al-Maliyyat al-Mal al-Milkiyyah al-Aqd, Ardan: Dari al-Nafa'is, 2009. 